\title{
The Global Crisis and Its Legal Impact on the Growth of Albanian Economy
}

$\mathrm{PhD}$ (c) Ervin Bacaj

PhD Evis Çelo

\author{
Prof.Asoc. Dr. Alba Robert Dumi \\ 1, 3 Economy Faculty "Ismail Qemali" Vlora University Albania \\ ${ }^{3}$ Letters Department, "Ismail Qemali" Vlora University Albania \\ Email: alba.besi12@gmail.com
}

\section{Doi:10.5901/mjss.2017.v8n1p184}

\begin{abstract}
We started as a crisis of high commodity prices, she quickly clarified the extent of the banking crisis and rapidly accelerated the financial crisis which culminated with the economic crisis, social and global, perhaps it was the heaviest one after the Second World - War. The consequences of this crisis was widely reflected in the deterioration of macroeconomic indicators of the budget, it appeared a significant decline in economic growth, a drop in revenues, an increase in unemployment and the fast increase of budget expenditures. The budget deficit and public debt grew at high rates, the cost and sources of financing of the economy became the most difficult and the most expensive. To stop the deterioration, the governments of many countries, regardless of their political spectrum supported the growth of aggregate demand, this process in many countries aggravated budget deficits. The primary task to overcome the crisis was a strategy that would ensure the sustainability of public finances in the countries affected by the crisis. The main difficulty faced was the global coordination such a global challenge. Researches can improve the profits of a company because of the potential capabilities of diversification with innovation performance or some have argued that the returns are increasing but this diversification has a very big risk. International expansion is very difficult to manage because there are a risk. Chief among them are economic and political risks because due to these risks by diversification of large firms are accustomed to the conditions of a market in competitive situations. The risk policy has to do with a government concentration creating much problem. The economic risk concerns exchange rates and market expansion line.
\end{abstract}

Keywords: Legal analyzes, Banking crisis, macroeconomic indicators, and budget expenditures.

\section{Introduction}

International Financial Institutions, general expertise in analyzing carefully the factors and consequences of the crisis, strongly recommended the necessity of maintaining macroeconomic stability. According to them, after stopping the deterioration of the economy, the countries affected by the crisis, should pay attention to strict control over the budget deficit, public debt, and the budget in general as necessary to restore macroeconomic stability.

In many countries of the European Union and beyond, the public debt rose sharply as a result of fiscal policy and increased of public spending beyond generating capacity of an economy. The increase in spending, not in the same dimension of economic growth and financial resources, forced governments to use debt instrument beyond "permissible limits".

"The recovery in Europe is underway, but still is lower than in many other regions of the world. Terms of the loan are still very strict, unemployment is high and still rising even more and the most important thing is that in many places, people are concerned about fiscal sustainability, which means declining confidence about stability "- Marek Belka, Director of the IMF's European Department ${ }^{1}$.

Government spending rose sharply (IMF today, the EC identified problems and are urging all countries except structural measures and strict control over costs) directly aggravating budget deficit. Even in our country, the deficit and debt growth came not only because of the impact of the global crisis, but also due to the lack of structural reforms and governmental populism with public finances. European countries, the control of the deficit combined with vigorous measures to control public spending (reduction of salaries and pensions in case of Spain, Ireland, Greece, Romania, but

${ }^{1}$ Regional Economic Outlook, June 10, 2010. 
also Italy) and the increase of revenue by introducing tax increases.( Quinn, R.E. Spreitzer, G.M \& Hart 1991)

\subsection{The Importance of Scientific Article}

International Monetary Fund and the European institutions by analyzing the economic and financial situations in many countries, have recommended interventions and adjustments in fiscal policy, which should focus on reasonable deficit reduction and public debt. Rising deficits and the public debt has now reached worrying levels. Nearly all countries are required to take the responsibility of controlling spending, including raising or lowering levels and real wages and pensions. These policies should consist in two directions: Firstly: control and reduction of budget expenditures, but not public investment. Secondly: revenue growth if this is considered necessary. (Vroom, V.H \& Yetton 1973)

\section{Literature Review and Hypotheses}

\subsection{Model Based on the average return}

This model implies that each organization has unique about resources which strengthens the basis for any strategy and is key to any source. A firm is included about opportunities that are managed dynamically by return on average. (Quinn, R.E. Spreitzer, G.M \& Hart 1991) According to this model, differences in firm performance in the time originally are directed on their resources than the features in the industry. A firm has different sources, but they operate without any particular industry. One other implication of this model is that as firms can not have a large area in the introduction to the industry. Resources are firm product inputs such as capital based on individual employee skills, finance, and talented managers. Resources of a firm can be classified into three main features: physical, human and organizational capital. Resources are accessible and tangible nature. (Source: Ministry of Finance, the Bank of Albania, INSTAT, (Statistical Bulletin 2014 year report.)

$\mathrm{H} 1$-What function performs the organization?

$\mathrm{H} 2-$ How the organization will perform these functions?

H3- Different organizations that will perform functions?

H4-Why is the organization for?

The goal shows what the firm wants to achieve. The best way for a company that wants to maximize shareholders' return is pursuing the strategy that maximize and the investment incomes. (Source: The UNDP report, Albania and the millennium development goals July 2010)

\section{Methodology and Research Goal}

Despite the focus on the collection of resources required by the strategic conditions and external environmental objections, this model suggests that the company's unique resources and capabilities provided are based on a strategy. Not all companies have the resources and skills they need to have the basics of a competitive advantage. This potential is realized when the resources and skills are valuable, rare, less costly, unsustainable. Resources are available to explode opportunities or neutralize the external environment. (Vroom, V.H \& Yetton 1973) They are rare when possessed by few if any of the potential competitors did not. They are less costly when their firms do not have the advantage of time.

Their combination must take into account the concrete economic realities of each country, depending on the fiscal space that the country has available to increase spending. International Monetary Fund identified 7 ways budgetary interventions during the global crisis, which can be found today in the intervention packages of different countries in the world. R. Anely, 1995

1. The growth of government consumption expenditure.

2. Increased government investment.

3. Increase in budgetary transfers for employment promotion policies, etc.

4. Increasing support for most affected social groups.

5. Reduction in work-taxation of social security contributions.

6. Indirect tax cuts VAT, Excise

7. Capital- reduction of taxation of corporate profits, the dividend.

Fiscal packages in different countries tended to be approximately $2 \%$ of GDP. Various debates were also an integral structure and size of the packages that changed no less from one place to another. The analysis of other experiences during the crisis concluded that about $2 / 3$ of the measures include cutting costs and focusing only $1 / 3$ of the 
taxes.

\subsection{A survey into global financial and economic crisis}

As well as other countries of Southeast Europe and Albania was influenced by the global financial and economic crisis. This crisis proved macroeconomic balance, macroeconomic stability and sustainability of the system of private financial system in 2009, the last year so there is a progressive slowdown in economic growth. The decline of economic growth is attributable to lower investment and export activity. The current account deficit at $15.3 \%$ of GDP one of the weaknesses of the Albanian economy and the budget deficit rose to $7 \%$ of GDP. ${ }^{2}$

Albanian economy since 1998 has proven stability and a favorable macro-economic development. Budget revenues, especially tax revenues have increased from year to year, thus creating the premises for a satisfactory increase in total revenues, as evidenced by the attached chart for the years 2002-2004 (Tremmoli XH, 2010)

Tab 1:

\begin{tabular}{|l|c|c|c|c|}
\hline & & The revenues from taxes & Public expense & fiscal balance \\
\hline Country & Period & & & \\
\hline Britain & $1931-34$ & $-0,1$ & $-3,7$ & 3,6 \\
\hline Britain & $1975-79$ & $-2,2$ & $-5,1$ & 2,9 \\
\hline Britain & $1982-88$ & $-4,9$ & $-9,2$ & 4,3 \\
\hline Canada & $1992-99$ & 3,7 & $-5,8$ & 9,5 \\
\hline Finland & $1994-2000$ & 5,3 & $-6,7$ & 12,0 \\
\hline Germany & $1996-2000$ & 0,7 & $-3,9$ & 4,6 \\
\hline Ireland & $1985-96$ & $-3,7$ & $-14,3$ & 10,6 \\
\hline Netherlands & $1993-97$ & $-2,5$ & $-3,9$ & 1,4 \\
\hline Sweden & $1993-2000$ & 7,0 & $-7,8$ & 14,8 \\
\hline
\end{tabular}

Source: Policy exchange. year 2000

\section{Albanian Economy Related to the Global Crisis; Restoration of Economic Stability Premise for the Success of a Successful Economic Model}

Today more than ever on political grounds, experts of the economy, civil society, and the business is discussed extensively about the effects of the global crisis on our economy. These graph indicators facilitate discussion about the effects of the crisis, helping us to focus on the analysis of concrete factors and the anti-crisis strategies.

In long public debates and overworked, it is easily distinguished the denying position of the government and progovernors and a more realistic view, more responsive from non-party experts and the opposition of the country. In some cases expertise is threatened by opposition political emotions. Government discusses the performance of Albania's as excellent toward global crisis and a model for all other countries.

In an environment with overloaded politics, this approach leaves little or no room for an analysis of the most professional, which would reduce the effect of psychological risks over banking system of the country, would reduce the fear to invest or consume and help stop deteriorating economic growth, unemployment and poverty. The opposition, independent experts but even international financial institutions also drew attention to the worsening budget deficit, rising public debt and current account deficit. Business itself requires changes to fiscal policies which must alleviate the difficulties faced. (Luthans, F \& Lockwood 1984)

So low level of integration, especially in the financial sector, a high degree of informality and resources inherited remittances, not only are the factors that make proud, but in any case of other crisis, because the structural reforms NEED and deepening of integration will lose weight as a buffer. That's why today and not later, we need to clarify and undertake economic policies, reforms and long-term celerity, that reduce the risk of recurrence and the risk of crises with larger size and heavier in the future. Hungary, Romania, Latvia or Estonia though EU member states are concrete cases warning of future risks.

\footnotetext{
${ }^{2}$ Gulio Tremonti, Italian Minister of Finance and Economy at the meeting of the International Monetary Fund and World Bank, held in Washington April 24, 2010.
} 


\subsection{Findings of this paper research}

In any national or international economic factors relating to the nature and economic direction in which firms develop their activities. They should regulate the overall effectiveness of the credit and income levels and trends available to individuals to spend. Inflation rate, those of interest and productivity growth are factors that the firm takes into account when making a meaningful strategic planning

Social factors, Social factors are those factors which include: the values, beliefs, attitudes, opinions and ways of life of individuals who are positioned in the outer areas of the firm. Recent changes show that there is a very large effect on the external environment by such factors as the role of women is growing more in the labor market. Large companies are also heavily influenced by the role of women in the organization that started many years ago with the production of equipment which help many women as production of finished and semi-finished and microwave ovens.

Political factors, These factors determine the legal parameters and rules within which the firm will operate. These factors are: antitrust law, tax programs, minimum wage legislation, programs of environmental protection from pollution. In general these factors reduce the possibility of increasing profit organizations.

Technological factors, Technological editors in chief are factors which help the company to avoid the old machinery and offering programs for the use of new machinery but also for the old ones. This technology promotes innovation and provides the company more opportunities to manufacture new products.

Ecological factors. Planning a good strategic plan, we can say that these factors are relevant to the local government and civil. It seems that the main contribution to environmental pollution must also take responsibility and to clean them from contamination. Factors that allow a good corporate development are cleaning the environment from pollution and the environment by not standing near intoxication corporate waste or firms.( Luthans, F \& Lockwood 1984)

Industrial environment and New entrants. New entrants are a threat to existing companies in the market but they also have to meet certain conditions before entering the market. Entry of new threats are: barriers to entry, the scales of economy, product differentiation, the initial entry control ,costs to be ahead, entries in the distribution channels, cost analysis regardless of scale economy.

Albanian SME each year gained experience, as far as businesses are being consolidated. The growth of SME in Albania has contributed to the economic development of the country. Based on data from INSTAT we have that $95.2 \%$ of SME are comprised by micro enterprises; $3.9 \%$ smaller ones; $0.7 \% 0.2 \%$ medium and large enterprises.

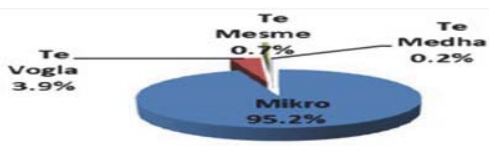

Graph 2: Divisions of SME by enterprises, Source: INSTAT (2012)

Based on the type of activity where these SME operate is noted that the Trade (wholesale and retail trade) is the sector where businesses operate more with $43.8 \%$. This can be explained by the fact that this kind of activity represents less barrier and requires less capital to initiate a venture, followed by the sector of hotels, cafes, restaurants by $16.1 \%$, other services $14.1 \%$, transport and telecommunication $10.2 \%$, industry by $9.8 \%$ and operating activities that fewer businesses are construction, agriculture and fishing respectively $4.3 \%$ and $1.8 \%$.

\subsection{Growth of SME in Albania and regional countries}

Private enterprises have begun to be established after 1990, while significant increase in their establishment is recorded in 2005-2009. After this period, we have significant decrease and then increase again. Doing a comparison according to "Doing Business" in Albania in comparing the progress of Albania with other countries in the region ,Macedonia is in the first place and then comes Albania, leaving behind other countries in the region, such as Montenegro, Serbia, Kosovo and Bosnia and Herzegovina.

However the growth of SME is often damaged by a series of direct or indirect barriers, raised by central or local government. Initially high rates of taxes and other barriers has led to a small number of Albanian SME to work informally and this does not mean that the number of informal businesses is setting to zero, but it is certainly limited. Albanian economy is characterized by a low level of credit caused by: the decline in demand for loans; a tightening of lending; low 
economic growth; low consumption of products; lack of economic capacity utilization of manufacturing.

The basic rate of interest (ALL- Lek ), for the period March 2014 is in historically low levels of 2.7\%. The problem of corruption, arbitrary behavior of tax refunds endless delay, the problem of building permits, especially as regards to the coast, are matters to be considered for an assessment of the business climate in Albania.

The rate in meeting the demands of domestic and foreign business investment will be crucial for the economic development of the country.

The most urgent problems related to the implementation of laws, infrastructure development, power supply, the improvement of the sector of water and sanitation, removal and treatment of waste and investment in vocational education, getting credit, protecting investors, paying taxes, enforcing contracts and resolving insolvency.

Improving the professional education sector provides jobs for people who have low qualifications. Factors that have lowered the assessment for our country as investment destination are the factor of corruption and criminality, as well as the unpredictability of fiscal policy. Local government and other stakeholders should contribute more to the promotion of SME in districts, the region and beyond, in order to enhance their image. It is created a favorable business climate where entrepreneurs can grow, but business representatives are seeking support from local and central government in their businesses.

\subsubsection{SMEs comparison with those of other countries}

The globalization of the economy, with changes brought progress and increased competition. SME have an important role in economic development. From the data we have that SME account about $99.8 \%$ of enterprises in the EU, estimated at 20.7 million businesses. From these the majority, about $92.2 \%$ are micro-enterprises $6.5 \%$ are classified as small and $1,1 \%$ are medium sized enterprises. Large enterprises accounted about $0.2 \%$

\begin{tabular}{|c|c|c|c|c|c|c|}
\hline & Milkro & TEvorala & Te mesme & SMIE & Te midha & Totall \\
\hline \multicolumn{7}{|c|}{ Numrí i ndêrmmarrjeve } \\
\hline Numri & 19143521 & 1357533 & 226573 & 20727627 & 43654 & 20771281 \\
\hline 96 & 92.2 & 6.5 & 1.1 & 99.8 & 0.2 & 100 \\
\hline \multicolumn{7}{|c|}{ Punésimi } \\
\hline Numni & 38395819 & 26771287 & 22310205 & 87477311 & 42318855 & 129796166 \\
\hline 96 & 29.6 & 20.6 & 17,2 & 67.4 & 32.6 & 100 \\
\hline
\end{tabular}

Chart 1: Number of Small- and Medium

Source: ENS, Euros tat / National Statistics (2012)

According to the World Bank report "Doing Business" in Albania. If we see the graph is a comparison of Albania with the regional countries in terms of ease of doing business procedures in Albania.

Albania globally is ranked 82 out of 183 economies on the ease of doing business.

For comparative ranking of economies and order at regional level are taken into account and other information for assessing how ease is for an entrepreneur in Albania to open a new business.

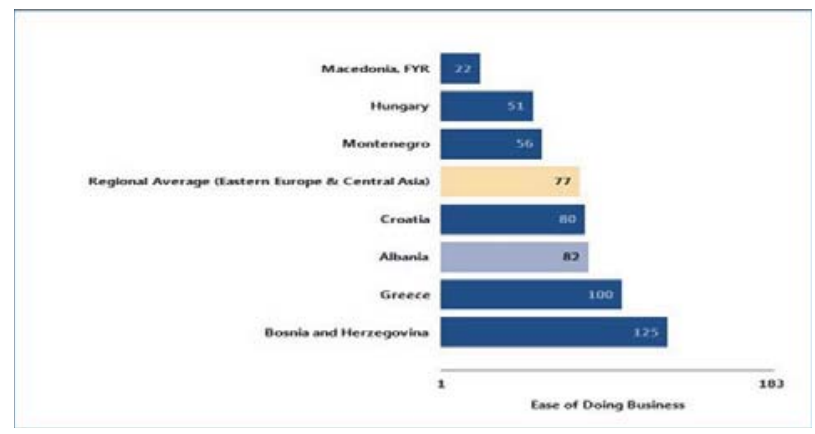

Graph 1: The ease of doing business in Albania

Source: Doing Business (2012) 
According to data collected by "Doing Business" to start a business in Albania requires at least 5 procedures, 5 days requires that at least pays $29 \%$ of income per capita and pay the minimum capital per capita income. Company Registration is made by the Business Registration Centre (NRC) through a one-stop app shop. It includes the registration fee at the municipal level and national level, enrollment in the Labor Inspectorate, the National Statistics Institute, social and health insurance.

1. A new electronic system contributes as a fast method and easy to record companies and other legal entities.

2. Above all business registration procedures take place for a day and in the same place.

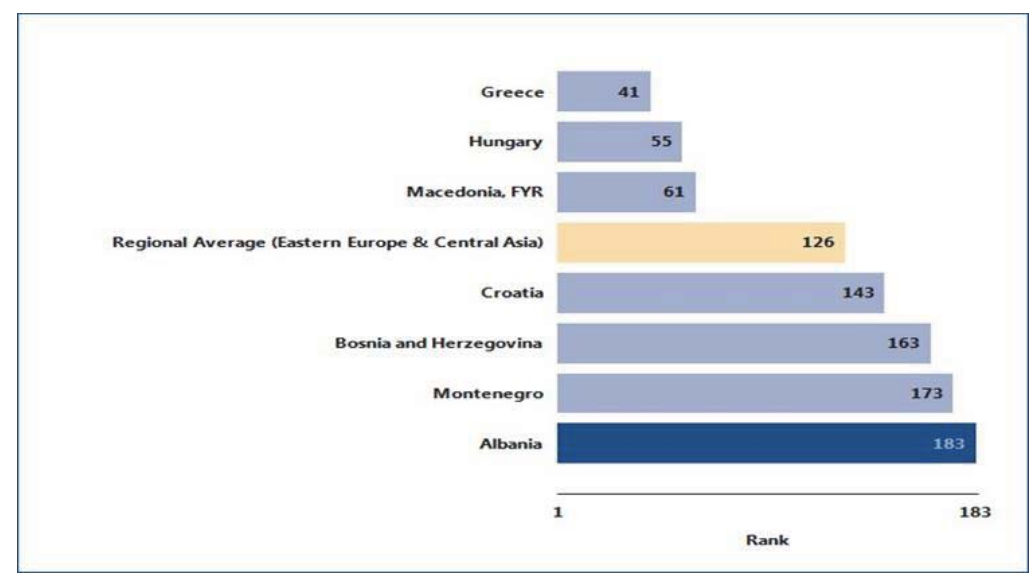

Graph 2: How easy is it to negotiate for construction permissions?

Source: Doing Business (2012)

Albania is ranked as $183^{\text {rd }}$ to negotiate for construction permission businesses compared with other countries, thus obtaining the permission procedures are a bit difficult.

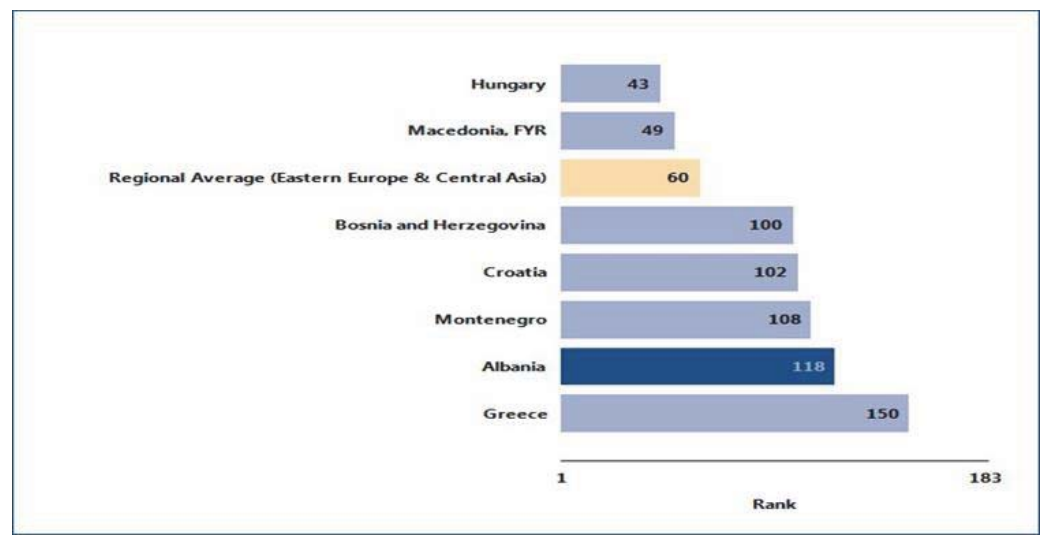

Graph 3: The ease of registering property

Source: Doing Business (2012)

Very difficult also is seen the process of registration of properties in Albania. It is ranked the $118^{\text {th }}$ 


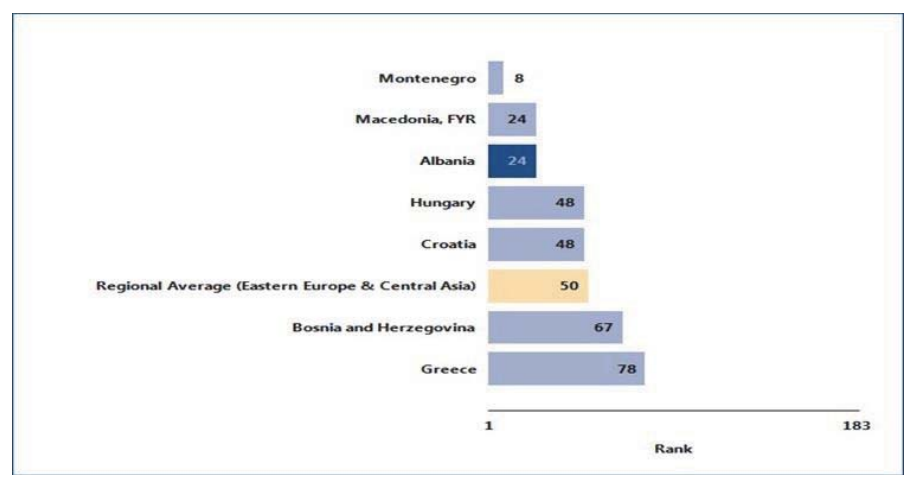

Graph 4: The ease of obtaining loans

Source: Doing Business (2012)

Meanwhile to borrow loans our country is ranked the 24-th.

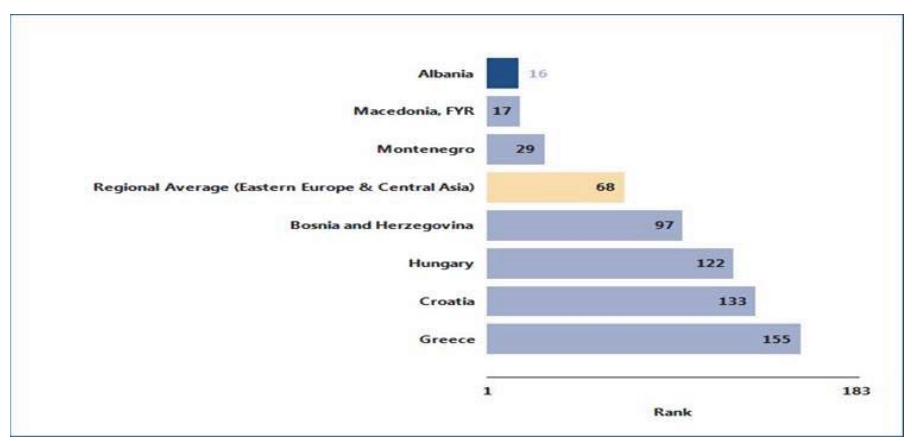

Graph 5: The strength protection of foreign investment index

Source: Doing Business (2012)

Also the protection of foreign investments appears very well compared with other countries, ranking it the16-th.

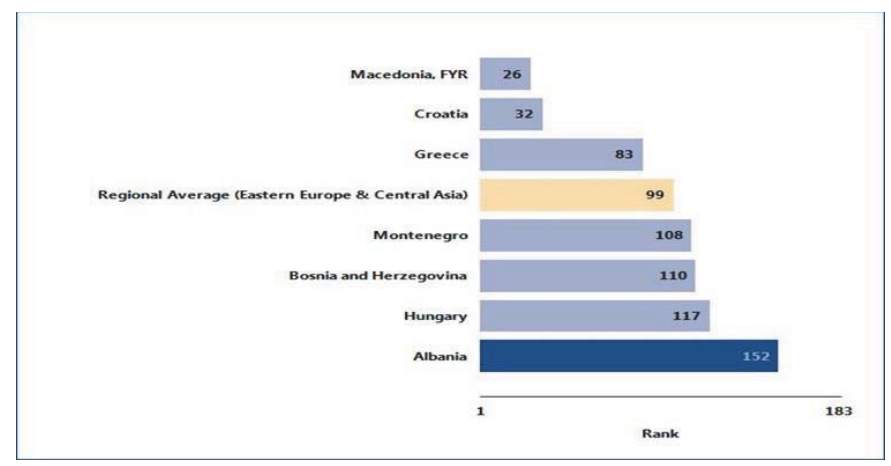

\section{Conclusions and Recommendations}

Our country's counted as the 152-nd for paying of taxes.

1. Government and public support for foreigners and investors by telling them how important it is to increase 
investment in the country.

2. The way of advertising, stable relations and corruption will allow foreigners to decide whether Albania will have a priority for investment. This means the level of employment growth that will improve living standards.

3. Despite the same desires and the same goals for investors and government the proper way is to create an appropriate strategy which includes an action plan to address future challenges. This will lead to higher investor confidence in the Albanian market.

The external environment of a firm consists of three main elements: remote environment, industrial environment and operating environment. Most firms in the external environment have increased problems. They grow in a very difficult and complex depending on an extension. The external environment or far consists of factors that directly affect their own space. These factors are: economic factors, social factors, political factors, technological factors, ecological factors. These factors are recognized with a term set by the great scholars of all ages known as PESTEL analysis.

Each company before the draft mission should recognize the economic goals of a business. Stockholders' of the organization 'are those individuals that help or affect the organization by the activity including investors, customers, suppliers, governments, competitors, trade unions, local government, public, shareholders, employees, Board of Directors and Chief Executive Officer.

Since 1960-1980 competitive environment was thought to be the main factor for the firms strategy was successful model I / O explains the pervasive influence of the external environment on firms with significant strategic actions. This model shows that the industries choose to try in every way a high influence on firm performance and that managers need to make their choice within the organization. The performance of the firm believe that being the first in the industry including economy of scale, barriers to entry, diversification of products and the degree of concentration. Based on the economy discipline external environment undertake to impose pressure and objections strategies will result in average returns. (Source: Ministry of Finance, the Bank of Albania, INSTAT, (Statistical Bulletin report.)

If the company does not support them and fulfill their interests and the latter, will not support their operations. Organizations have a relationship of interdependence with their stockholder. We have clarified that the amortized factors of the global crisis, so why Albania was not affected as much as other countries, without denying government involvement in increasing investment in public places, the quality and effectiveness of which were vulnerable, stand to some weakness in our economy.

\section{References}

Luthans, F \& Lockwood, D.L. Toward an observation system for measuring leader behavior in natural settings. In J.G. Hunt, D. Hosking, C.A> Schriesheim, and R.Steward (eds), Leaders and managers: international perspectives on managerial behavior and leadership. New York : Pergamon Press, 1984.

Mintzberg, H. The nature of managerial work. New York: Harper and row, 1973

Morse, J.J \& Wagner, F.R. Measuring the process of managerial effectiveness. Academy of Management Journal, 1978, 21, 23-35.

Park, R.E. behind our masks. Survey, 1926, 56, 135-139.

Quinn, R.E. Beyond rational management. Mastering the paradoxes and competing demands of high performance. San Francisco: Jossey-Bass, 1988.

Quinn, R.E. Spreitzer, G.M \& Hart, S.Challenging the assumptions of bipolarity: interpenetration and managerial effectiveness. In S.Srivastva and R. Fry (eds). Executive continuity. San Francisco, CA: Jossey-Bass, 1991.

Schlenker, B.R. Impression management: the self-concept, social identity and interpersonal relations.Monterey,CA: Brooks/Cole Publishing Company, 1980.

Staw, B.M \& Ross, J. Journal of Applied Psychology, 1980, 65(3), 249-260.

Stogdill, R.M. personal factors associated with leadership: A survey of the literature. Journal of psychology, 1948/, $25,35-71$.

Van Fleet, D.D \& Yukl, G.A. military leadership: an organizational behavior perspective. Greenwich, CT: JAI Press, 1986.

Vroom, V.H \& Yetton, E.W. Leadership and decision making. Pittsburgh University Press, 1973.

Wheaton, B. Assesment of fit in overidentified models with latent variables. In J.s. Long (ed), Common problems/propers solutions: Avoiding error in quantitative research. Beverly Hills, CA: Sage, 1988.

Pinder, C, Pinto, P.R \& England, G.w. Behavioral Style and Personal Characteristics of Managers. Technical report, University of Minnesota, Center for the study of organizational performance and human effectiveness, Mineapolis, 1973.

Yukl, G.A. A New Taxonomy for Intergrating Diverse Perspectives On Managerial Behavior. Paper presented at the American Psychological Association meeting, New York, 1987.

Yukl, G.A. leadership in organization. Englewood Cliffs, NJ: Prentice-Hall, 1989. (a) 